\title{
COMPARISON OF THE EFFECTIVENESS OF THE USE OF GRADED INQUIRIES IN BIOCHEMISTRY LEARNING
}

\author{
Yunita Arian Sani Anwar and Eka Junaidi \\ Chemistry Education Study Program FTTE University of Mataram, Mataram, Indonesia \\ *Email: yunita@unram.ac.id
}

Acceped: July 29 2021. Approved: Sept 01 2021. Published: Sept 032021

\begin{abstract}
This study aims to compare the effectiveness of guided inquiry, open inquiry, and tiered inquiry in biochemistry learning. The effectiveness is seen from the product-process perspective, i.e., by looking at critical thinking scores and responses of lecturers' teaching activities. This study involved three groups treated with guided inquiry (level 1), open inquiry (level 2), and tiered inquiry (level 1 to level 2). The number of respondents was 72 students spread over the three groups. Before being given treatment, the three groups were tested for prior knowledge, and it was obtained that the three groups had the same initial ability. The research instrument used was critical thinking questions and a questionnaire of responses to the learning process. The results showed that the group with tiered inquiry treatment had the highest critical thinking score, while open inquiry had the lowest score. It is in line with the respondents' responses related to the learning process. Students feel easier and more comfortable in the tiered inquiry process than the guided and open inquiries. The results of the Mann-Whitney $U$ test analysis on the three treatments showed that the three groups had significantly different critical thinking scores. It can be concluded that tiered inquiry is more effective in Biochemistry learning than guided and open inquiries.
\end{abstract}

Keywords: Biochemistry, critical thinking, inquiry

\section{INTRODUCTION}

The demands of 21 st-century education currently produce a learning process that can train four things, i.e., knowledge, skills, work habits, and character. Critical thinking, creative thinking, communication, and collaboration are forms of skills needed by students to adapt to changing times. These skills are expected to be trained on students, including students at the university level [1].

Inquiry is one of the recommended learning models in training students' thinking skills. This model is in accordance with constructivism theory, where students are given a learning experience to be able to construct their understanding to form a new understanding [2]. In Chemistry learning, the ability to connect previous concepts with new concepts can be stored in long-term memory [3,4]. The concept held in the long term is one of the characteristics of meaningful learning expected in the learning process at every level [5].

Learning with the inquiry model is reported to train students' practical and thinking skills [6-8]. In addition, allowing students to discover the learning characteristics using the inquiry model can develop scientific attitudes and students' motivation [9]. The application of the inquiry model can be used in learning that requires practicum so that it can be applied in science learning.

Inquiry is divided into four levels, i.e., level 0 (verification), level 1 (structured inquiry), level 2 (guided inquiry), and level 3 (open inquiry) [10]. Descriptions of the four levels are shown in Table 1. The use of level 0 inquiry is often used and is often equated with the expository method where problems to problem-solving are given to students by lecturers. Inquiry level 1 and 2 technically provide independence to students, where at level 1 , the completion stage is developed by students, and at level 2 , methods and solutions are developed by students. It is the reason for the two levels of inquiry reported to be able to train students' independence in learning science to increase their understanding of chemical concepts [11-13].

Table 1. Levels of Inquiry

\begin{tabular}{clll}
\hline Level & Problems & \multicolumn{1}{c}{ Methods } & Completion \\
\hline 0 & Given to & Given to & Given to \\
& students & students & students \\
1 & Given to & Given to & Developed by \\
& students & students & students \\
2 & Given to & Developed by & Developed by \\
& students & students & students \\
3 & Developed & Developed by & Developed by \\
& by students & students & students \\
\hline
\end{tabular}

Biochemistry is one of the compulsory subjects that Chemistry students must take. The characteristics of the concepts studied are related to concepts that are quite dense and are applicable. Although it is abstract and difficult to understand, the concepts learned are interesting in the opinion of most students [14]. The dense concepts cause the lecture method to be often chosen in explaining Biochemistry concepts in class. It causes learning less meaningful $[15,16]$.

Effective learning can be described in three perspectives. The first is called the product definition. Learning is said to be effective if there are positive changes in students. These changes may include learning outcomes, skills, or other variables. The second is called the process definition. Learning is said to be effective if the teacher's activities are better than before and impact positive responses from students. The third is called the process-product 
definition. Learning is said to be effective if the teacher's activities are better and change student attitudes to be better [17].

The use of inquiry has been widely applied in science learning, including Biochemistry. However, the levels used vary, so there needs to be a comparison at each level. The use of inquiry at each level needs to consider students' conditions and the characteristics of the concept. Thus, this study aims to compare the use of inquiry at several levels and with their modifications to be considered in their application.

\section{RESEARCH METHOD}

\section{Research Design}

This research is descriptive quantitative research comparing student learning outcomes in the use of inquiry in Biochemistry learning. The levels being compared are levels 2, 3, and those conducted in stages. Levels 0 and 1 are inquiry levels that have been used for a long time. There were 3 treatment groups: the group that uses inquiry levels 2 and 3 and the group that uses both levels but in stages. The division of the groups is shown in Table 2.

Table 2. Distribution of Treatment Groups

\begin{tabular}{lll}
\hline Groups & Levels of Inquiry & Total \\
\hline Group 1 & Level 2 & 23 \\
Group 2 & Level 3 & 24 \\
Group 3 & Graded from level & 25 \\
& 2 to level 3 & \\
\hline
\end{tabular}

Before being given treatment, both groups were tested for initial knowledge using organic chemistry questions because the organic chemistry course is a prerequisite course for taking biochemistry courses. The initial knowledge test contains the concepts related to the biochemistry course, such as functional groups, molecular structure, physical properties, and chemical properties related to functional groups.

\section{Learning Scenario}

Learning scenarios at each level of inquiry are shown in Table 3.

Table 3. Learning Scenarios

\begin{tabular}{|c|c|}
\hline Level & Scenarios \\
\hline 1 & $\begin{array}{l}\text { a. Students are given an explanation of the } \\
\text { structure and properties of proteins. } \\
\text { b. Students are given assignments to learn } \\
\text { how to do quantitative analysis of proteins } \\
\text { in samples. } \\
\text { c. Students were asked questions related to } \\
\text { the quantitative analysis of proteins. This } \\
\text { types of questions were a question that } \\
\text { can practice critical thinking skills. } \\
\text { d. Students collect information and answer } \\
\text { questions based on the information } \\
\text { obtained independently. } \\
\text { e. Steps a-d are repeated for the topic of } \\
\text { enzymes. }\end{array}$ \\
\hline
\end{tabular}

\begin{tabular}{ll}
\hline 2 & a. $\begin{array}{l}\text { Students are given an explanation of the } \\
\text { structure and properties of proteins. }\end{array}$ \\
b. Students are given assignments to learn \\
how to do quantitative analysis of proteins \\
in samples. \\
c. $\begin{array}{l}\text { Students design independent questions } \\
\text { related to quantitative protein analysis. }\end{array}$ \\
d. Students collect information and answer \\
problems designed based on the \\
information obtained independently. \\
e. $\begin{array}{l}\text { Steps a-d are repeated for the topic of } \\
\text { enzymes. }\end{array}$ \\
\hline Graded & a. $\begin{array}{l}\text { Follow the same steps at inquiry level } 1 \\
\text { for the topic of protein. }\end{array}$ \\
b. Follow the same steps at inquiry level 2 \\
for the topic of enzymes.
\end{tabular}

\section{Research Instruments}

This study uses three instruments: preliminary knowledge test instruments, critical thinking questions, and observation sheets. Initial knowledge and critical thinking test instruments had been tested for the content validity, construct validity, and reliability to be used as measuring tools. Five critical thinking indicators were measured: remembering, making assumptions, developing hypotheses, testing hypotheses, and developing conclusions. The observation sheet had been analyzed by experts to be used as a research instrument.

\section{Data Analysis Technique}

The data obtained from the initial knowledge test and critical thinking were tabulated and averaged. The three groups were then analyzed after the treatments using the Mann-Whitney test. Calculation of the scores difference in each group of respondents used the SPSS 21 [18].

\section{RESULTS AND DISCUSSION}

Students' scores in answering critical thinking questions showed the highest average in the group treated with graded inquiry $(\mathrm{X}=82.56$; $\mathrm{SD}=7.89$ ). The group treated with open inquiry (level 2) showed the lowest average, $63.09(\mathrm{SD}=6.92)$, while the score of the guided inquiry group (level 1) was 73 (SD = 7.47). The average score of students' critical thinking in the three groups is shown in Figure 1.

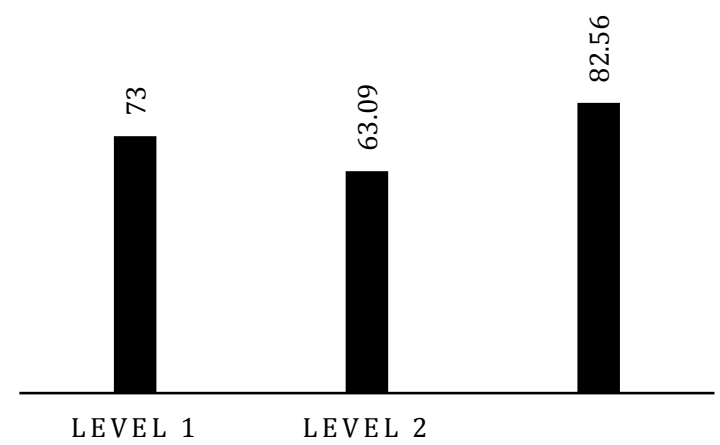

Figure 1. Critical Thinking Scores of the Treatment Groups 
The score of each indicator in the three groups shows a varying average. In the three groups, the remembering and making assumptions indicators gave the highest average score, while the score of developing conclusions gave the lowest average in the three treatment groups (Figure 2). The Mann-Whitney $\mathrm{U}$ test analysis to compare the scores in the three groups showed that the three groups differed significantly (Table 4).

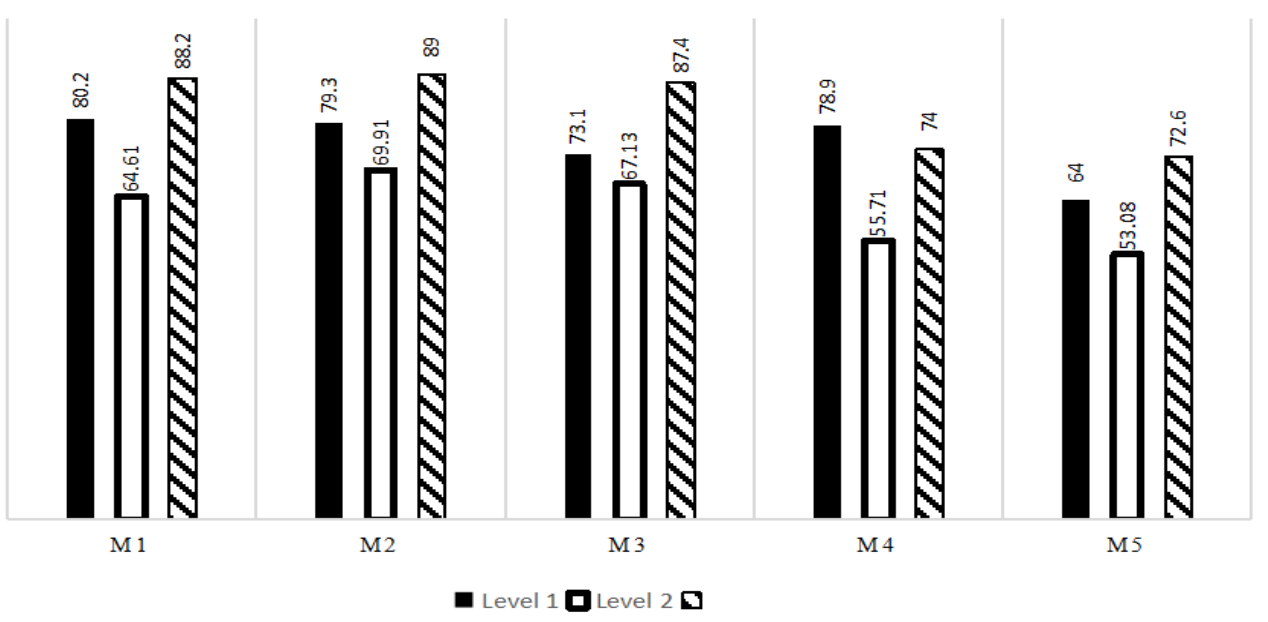

Figure 2. Critical Thinking Scores of Each Indicator of the Three Treatments

Table 4. Analysis of Mann-Whitney U Test of the Three Treatments

\begin{tabular}{llll}
\hline & \multicolumn{3}{c}{ Inquiry Groups } \\
\cline { 2 - 4 } & Inquiry 1 & Inquiry 2 & Graded \\
\hline Inquiry 1 & & $\mathrm{p}<0,05 ;$ & $\mathrm{p}<0,05 ;$ \\
& & $\mathrm{Z}=-1,282$ & $\mathrm{Z}=-1,134$ \\
\hline Inquiry 2 & $\mathrm{p}<0,05 ;$ & & $\mathrm{p}<0,05 ;$ \\
& $\mathrm{Z}=-1,282$ & & $\mathrm{Z}=-3,685$ \\
\hline Graded & $\mathrm{p}<0,05 ;$ & $\mathrm{p}<0,05 ;$ & \\
& $\mathrm{Z}=-1,134$ & $\mathrm{Z}=-3,685$ & \\
\hline
\end{tabular}

Analysis of student responses showed different responses in the three groups. $68 \%$ and $65 \%$ understood the learning scenario in the guided and graded inquiry groups, while the rest felt doubtful. In the guided inquiry group, $52 \%$ of the students understood the scenario, and the rest felt confused in following the learning scenario.

The guided inquiry has stages that train students' independence better than conventional learning. Although lecturers' role is still more than open inquiry, this stage can train students' readiness in designing problems and planning for solutions [19,20]. Activities of collecting information and solving problems based on the information collected can improve students' ability to argue and increase their motivation [19,21,22].

Information gathering at the inquiry stage helps students relate to the given problems. This ability helps students analyze and make arguments related to the answers to the given problems [23]. If their arguments and answers to problems are correct, students' confidence increases to study other problems. The arguments made help students to construct new understandings so that concepts can be stored in their long-term memory [24,25].

In open inquiry, students were allowed to determine their problems and seek solutions to them. This study found that students' critical thinking scores on the application of open inquiry were lower than the other two treatments. This can be caused by the habits that students in the open inquiry had not conducted. Students are not accustomed to using open inquiry so far. Thus, using open inquiry directly can make students uncomfortable because they are accustomed to learning with the material provided by lecturers [26,27].

The use of graded inquiry showed the highest critical thinking score compared to the guided and open inquiries. Graded inquiry helps students think in stages, starting from simple things trained in guided inquiry to being demanded to be independent in open inquiry. It is in line with previous research reported that inquiry conducted in stages allowed students to solve problems ranging from those designed for them to those designed independently [28-30].

The inquiry's success can be influenced by the beliefs built up by the students themselves. This belief can be built in four ways: efforts to succeed, learning from success, building motivation, and suggestions related to the belief that it can work. Positive student responses to graded inquiry indicated a source of motivation that could be the factor of the high critical thinking scores [31-35].

In the three perspectives of effective learning, it can be seen that the use of graded inquiry gives a higher critical thinking score than the guided and open inquiries. This shows that the use of graded inquiry is more effective than the guided and open inquiry. In addition, the positive responses to the use of graded 
inquiry were higher than the two treatment groups. Thus, from the perspective of the graded inquiry process, it was more effectively applied to biochemistry learning.

\section{CONCLUSION}

The use of three types of inquiry gave significantly different critical thinking scores. The group showed the highest critical thinking score with graded inquiry treatment followed by guided inquiry and open inquiry. The application of graded inquiry is more effective from the perspective of product and process. It can be seen from the higher critical thinking scores and better responses to the learning process in the group with graded inquiry treatment.

\section{REFERENCES}

[1] Saavedra, A.R., \& Opfer, V.D. (2012). Teaching and learning $21^{\text {st }}$ century skills: lessons from the learning sciences. London: RAND Corporation.

[2] Gabel, D. (1999). Improving teaching and learning through chemistry education research: a look to the future. Journal of Chemical Education, 76(4), 548-553.

[3] Greenbowe, T. J., \& Hand, B. M. (2005). Introduction to science writing heuristic. In Peinta, N. J., Cooper, M., \& Greenbowe, T. J. (Eds.), chemists guide to effective teaching. (p.140). Upper Saddle River, NJ: Prentice Hall.

[4] Johnstone, A.H. (1997). Chemistry teachingscience or alchemy? Journal of Chemical Education, 74(3), 262-268.

[5] Ausubel, D.P. (1968). Educational psychology: a cognitive view. New York: Holt, Rinehart, and Winston.

[6] Cacciatore, K.L., \& Sevian, H. (2009). Incrementally approaching an inquiry lab curriculum: can changing a single laboratory experiment improve student performance in general chemistry? Journal of Chemical Education, 86(4), 498-505.

[7] Fakayode, S.O. (2014). Guided-Inquiry Laboratory Experiments in the Analytical Chemistry Laboratory Curriculum. Analytical and Bioanalytical Chemistry, 406, 1267-1271.

[8] Stout, R.P. (2016). $\mathrm{CO}_{2}$ investigations: an open inquiry experiment for general chemistry. Journal of Chemical Education, 93(4), 713-717.

[9] Ketpichainarong, W., Panijpan, B., \& Ruenwangsa, P. (2010). Enhanced learning of biotechnology students by an inquiry-based cellulase laboratory. International Journal Environmental \& Science Education, 5(2), 169187

[10] Fay, M.E., Grove, N.P., Towns, M.H., \& Lowery, S. (2007). A rubric to characterize inquiry in the undergraduate chemistry laboratory. Chemistry Education Research and Practice, 8(2), 212-219.

[11] Sedwick, V., Leal, A., Turner, D., \& Kanu, A.B. (2018). Guided inquiry learning experience in quantitative analysis. Journal of Chemical Education, 95(3), 451-455.

[12] Winkelmann, K., Baloga, M., Marcinkowski, T., Giannoulis, C., Anquandah, G., \& Cohen, P. (2015). Improving students' inquiry skills and self-efficacy through research-inspired modules in the general chemistry laboratory. Journal of Chemical Education, 92(2), 247-255.

[13] Conway, J.C. (2014). Effects of guided inquiry versus lecture instruction on final grade distribution in a one-semester organic and biochemistry course. Journal of Chemical Education, 91(4), 480-483.

[14] Jidsejo, A., Oscarsson, M., Karlsson, K. G., \& Stromdahl, H. (2009). Science for all or science for some: what Swedish students want to learn about in secondary science and technology and their opinions on science lessons. Nordina, 11(2), 213-229.

[15] Varghese, J., Faith, M., \& Jacob, M. (2012). Impact of e-resources on learning in biochemistry: first-year medical students perceptions. BMC Medical Education, 12(21), 19.

[16] Broman, K., Ekborg, M., \& Johnels, J. (2011). Chemistry in crisis? Perspectives on teaching and learning chemistry in Swedish upper secondary schools. Nordina, 7(1), 43-53.

[17] Abrami, P.C., d'Appoilonia, S., \& Rosenfield, S. (1997). The dimensionality of student ratings of instruction: what we know and what we do not. In R.P. Perry \& J.C.Smart (Eds). Effective teaching in higher education: research and practice (pp.321-324). New York: Agathon Press.

[18] Ghozali, I. (2013). Aplikasi analisis multivariate dengan program IBM SPSS 21 Update PLS Regresi. Semarang: Universitas Diponegoro.

[19] JeanBurnham, J.A. (2013). Opportunistic use of students for solving laboratory problems: twelve heads are better than one. NDIR, 9(1), 42-48.

[20] Jolley, D.F., S.R. Wilson, C. Kelso, G. O'Brien, C.E. Mason. (2016). Analytical thinking, analytical action: using prelab video demonstrations and e-quizzes to improve undergraduate preparedness for analytical chemistry practical classes. Journal of Chemical Education, 93(11), 1855-1862.

[21] Walker, J.P, V. Sampson. (2013). Argumentdriven inquiry: using the laboratory to improve undergraduates' science writing skills through meaningful science writing, peer-review, and revision. Journal of Chemical Education, 90, 1269-1274.

[22] Miller, D.K., P.L. Lang. (2016). Using the universal design for learning approach in science laboratories to minimize student stress. Journal of Chemical Education, 93(11), 1823-1828.

[23] Hensiek, S., B.K. DeKorver, C.J. Harwood, J. Fish, K. O Shea, M. Towns. (2016). Improving and assessing student hands-on laboratory skills 
through digital badging. Journal of Chemical Education, 93(11), 1847-1854.

[24] Pickering, M. (1987) What goes on in students' heads in laboratory? Journal of Chemical Education, 64, 521-523.

[25] Gasper, B.J., S.M. Gardner. (2013). Engaging students in authentic microbiology research in an introductory biology laboratory course is correlated with gains in student understanding of the nature of authentic research and critical thinking. Microbiology and Biomolecular Education, 14(1), 25-34.

[26] Cheung, D. (2011). Evaluating student attitudes toward chemistry lessons to enhance teaching in the secondary schools. Educación Química, 22(2), 1-8.

[27] Chatterjee, S., V.M. Williamson, K. Mccann, M.L. Peck. (2009). Surveying students' attitudes and perceptions toward guided-inquiry and openinquiry laboratories. Journal Chemical of Education, 86(12), 1427.

[28] Anwar, Y.A.S. (2020). The multilevel inquiry approach to achieving meaningful learning in biochemistry course. Biochemistry ang Molecular Biology Education, 48(1), 28-37.

[29] M. Kakisako, K. Nishikawa, M. Nakano, K.S. Harada, T.Tomoyuki, T. Tatsuoka, N. Koga. (2016). Stepwise inquiry into hard water in a high school chemistry laboratory. Journal Chemical of Education, 93(11), 1923-1928.

[30] Wildan, W., Hakim, A., Siahaan, J., Anwar, Y.A.S. (2019). The Stepwise of Inquiry Approach to Improve Communications Skills and Scientific Attitudes in Biochemistry Course. International of Journal Instruction, 12 (4), 407422.

[31] Wahdah, N. F., Jufri, A. W., \& Zulkifli, L. (2016). Jurnal Belajar Sebagai Sarana Pengembangan Kemampuan Metakognisi Siswa. Jurnal Pijar Mipa, 11(1).

[32] Galloway, K.R., \& Bretz, S.L. (2015). Measuring meaningful learning in the undergraduate general chemistry and organic chemistry laboratories: a longitudinal study. Journal of Chemical Education, 92(12), 2019-2030.

[33] Qomaliyah, E. N., Sukib, S., \& Loka, I. N. (2017). Pengaruh model pembelajaran inkuiri terbimbing berbasis literasi sains terhadap hasil belajar materi pokok larutan penyangga. Jurnal Pijar Mipa, 11(2).

[34] Niedenthal, P.M. (2007). Embodying emotion. Science, 316, 1002-1005.

[35] Touroutoglou, A., Lindquist, K.A., Dickerson, B.C., \& Barrett, L.F. (2015). Intrinsic connectivity in the human brain does not reveal networks for 'basic emotions. Social Cognitive and Affective Neuroscience Advance, 10(9), 1257-1265. 